\title{
Concepts of ethics in Applied Linguistics research ${ }^{1}$
}

\author{
Alex Alves Egido \\ PPGEL/Universidade Estadual de Londrina \\ egido.alex.alves@gmail.com
}

\begin{abstract}
Ethics in research has drawn attention of applied linguists in the past years. Such consideration has created room to both theoretical propositions and practical actions. This article aims at arguing that the adoption and discussion of ethics in research is not solely related to physical or intentional harm and at recommending that applied linguists reflect on the ethical dimension(s) of their studies, as well as incorporate those reflections on their research reports. In order to achieve those goals, theoretical propositions are discussed and illustrated in terms of traditional and emergent ethics dimensions.
\end{abstract}

Keywords: Ethics terminologies. Researcher-participant relations. Ethical dilemmas.

\section{Resumo}

A ética na pesquisa tem chamado a atenção de linguistas aplicados nos últimos anos. Essa consideração criou espaço para proposições teóricas e ações práticas. Este artigo objetiva argumentar que a adoção e discussão da ética em pesquisa não está relacionada apenas a danos físicos ou intencionais, e recomendar que linguistas aplicados reflitam sobre a(s) dimensão(s) ética(s) de seus estudos, bem como a(s) incorpore $(\mathrm{m})$ em seus relatos de pesquisa. Para atingir esses objetivos, proposições teóricas são discutidas e ilustradas em termos de dimensões éticas tradicionais e emergentes.

Palavras-chave: Terminologias de ética em pesquisa. Relações pesquisadorparticipante. Dilemas éticos.

\footnotetext{
${ }^{1}$ I am deeply thankful to Professors Lilian Kemmer Chimentão, PhD (Universidade Estadual de Londrina, Brazil) and Marilys Guillemin, $\mathrm{PhD}$ (University of Melbourne, Australia) for their readings and thought-provoking comments. The limitations of this writing are, however, my own.
} 


\section{Introduction}

'But I do not do or intend any harm', which "[...] is anything but straightforward” (CLARK; SHARF, 2006, p. 402), is a statement I often hear from some applied linguists as a reason for not employing either traditional or emergent ethics perspectives in their ongoing investigations. Even though "[p]rofessional etiquette uniformly concurs that no one deserves harm or embarrassment as a result of insensitive research practices" (CHRISTIANS, 2000, p. 145), applied linguists may unconsciously cause it to their research participants; as all researchers may cause too, regardless the area of knowledge.

I aim at arguing that the adoption and discussion of ethics in research is not solely related to physical or intentional harm (LEVY; BERGERON, 2010). This still general impression is rooted in researchers' minds because "[t]he traditional starting point and focus for discussions of research ethics has been the ethical principles formulated for biomedical research, usually quantitative in nature" (GUILLEMIN; GILLAM, 2004, p. 262). Consequently, my ultimate goal is to recommend that applied linguists reflect on the ethical dimension(s) of their studies, as well as incorporate those reflections on their research reports.

The emergence of ethics in research dates back to post Nuremberg trials, which I discuss in the following sections. Their authors are primarily from distinct areas of study, namely: anthropology, feminism, political science, sociology, and sociolinguistics (CAMERON et al, 1992). Further than the emergence, it is currently possible to depict the expansion of such field by means of a set of publications, which I classify between research reports stressing ethical discussions based on investigators' experiences (CHIMENTÃO; REIS, 2019; DE COSTA, 2014; 2015; 2016) and conceptual propositions (CHRISTIANS, 2000; GUILLEMIN; GILLAM, 2004; KUBANYIOVA, 2008; REIS; EGIDO, 2017), herein I review the latter.

As to illustrate this variety of terminology and practices that constitute the ethics in research field, within the area of Applied Linguistics, I review North American (CHRISTIANS, 2000), Australian (GUILLEMIN; GILLAM, 2004), Brazilian (REIS; EGIDO, 2017), and British (KUBANYIOVA, 2008) papers that conceptualize such term (viz. ethics in research). Even though, it is important to clarify that some of these authors 
are not applied linguists. By doing so, I also address Ducet's (2000) emphasis to the necessity of reinterpreting and expanding the concepts of ethics in research. I understand the papers I herein focus on do it successfully.

On this theoretical paper, I first conceptualize and characterize the traditional ethics perspective, which is followed by the emergent one. In each section, I also exemplify such perspectives by briefly recalling research reports that are illustrative. Then, I comment on their similarities and differences, highlighting the coexistence of both ethical dimensions ${ }^{2}$. Lastly, I address some final remarks and refer to my own ethics, which oriented me during this study.

\section{Traditional ethics perspective}

I named this section as 'traditional ethics perspective' in order to cover four terminologies, which are interchangeable: bureaucratic (REIS; EGIDO, 2017), formal (CHRISTIANS, 2000), macroethics (KUBANYIOVA, 2008), and procedural (GUILLEMIN; GILLAM, 2004). In general terms, they refer to "[...] a formal process of bureaucratic oversight" (HAGGERTY, 2004, p. 393), which is sometimes seen by novice researchers as "c'est la police!" (DUCET, 2000, p. 2). I employed the attribute 'traditional' to broadly refer to the terminologies due to their observance to historical events and both international and national documents, which are about human rights.

By addressing some historical events and documents, I intend to contextualize the scenario in which the terminologies of ethical researches were proposed. To exemplify its adoption, I cite two research reports from two distinct geographical locations (i.e. North America and Brazil). Finally, I make a synthesis of the traditional ethics perspective.

${ }^{2}$ On this paper, I take 'dimension' and 'perspective' as synonyms. 


\subsection{Historical notes ${ }^{3}$}

Although unethical research practices date centuries back (see, for example, Foucault (1988 [1961])), they were only properly addressed after the II World War (1939-1946). Secret medical investigations (and others) carried out by German physicians during that time boosted the creation of international regulations regarding human rights (e.g. Universal Declaration of Human Rights (UNITED NATIONS, 1948), and investigative practices in the medical area (e.g. HELSINKI DECLARATION, 1964; NUREMBERG CODE, 1949). These international regulations guided the creation of local regulations throughout the world in the following decades (e.g. Conselho Nacional De Saúde, 1988).

Based strictly on the traditional ethics perspective, an ethical research is characterized by the adoption of ethical research norms prescribed by regulatory institutions. Such institutions can be both local and federal, university's review boards, as previously stated by Kubanyiova (2008), and Ministry of Health laws, respectively.

Some of the ethical practices prescribed by the protocols are: (i) the submission of the research design to the evaluation of an Institutional Review Board (henceforth, IRB), (ii) the presentation of the study to possible participants, (iii) when it is the case, the register of their agreement ${ }^{4}$, and (iv) the safeguard of their identities. However, some research proposals may observe additional ethical considerations indicated by an IRB (e.g. HAMID, 2010).

As the time went on, it became clear that investigations conducted in the Social Sciences also required ethical care. Then, institutions, both governmental and professional, proposed additional regulations (e.g. BRITISH EDUCATIONAL RESEARCH ASSOCIATION, 2011; 2018; CONSELHO NACIONAL DE SAÚDE, 2016). Christians's (2000) remarks

\footnotetext{
${ }^{3}$ I recommend a few publications to a comprehensive historical review on ethics in research (ANDRADE, 2017), in applied linguistics research (EGIDO, 2019) and in medical research (DUCET, 2000).

${ }^{4}$ For instance, according to the Brazilian legislation (Resolution no. 510/2016 Conselho Nacional de Saúde, 2016), it can be register either in audio recording or in written. When the former mean is selected, it has to be explained to IRB the reasons and reassure the anonymity.
} 
are one example of such reinterpretation of ethical considerations to the Social Sciences.

Relying mostly on utilitarian philosophers, Christians (2000) proposes four recurrent stated elements by the major scholarly institutions, namely: Informed consent, deception, privacy and confidentiality, and accuracy.

The distension of traditional ethics considerations to Social Sciences indicates "[...] the social sciences are now also recognized as a riskproducing endeavor" (HAGGERTY, 2004, p. 392). Even though the institutional research norms are often dissevered between Medical and Social Sciences researches, the ethics terminologies I discuss on the following setting are mostly related to the Applied Linguistics area.

\subsection{Concepts of Ethics}

Herein, I center on the four terminologies vested with traditional ethics perspective. Guillemin and Gillam (2004, p. 263), Australian scholars in the Health Sciences, portray the procedural ethics as the one that "[...] usually involves seeking approval from a relevant ethics committee to undertake research involving humans [...]". This authors' specific definition centers on the practice of submitting a research proposal to an IRB. I stress that it is implicit in this practice the necessity of an informed consent, anonymity safeguard, etc.

In Kubanyiova's (2008, p. 504) understanding, macroethics " $[\ldots]$ refers to the procedural ethics of IRB protocols based on general ethical principles, which are also incorporated in professional codes of conduct". The British professor of Language Education resembles Guillemin and Gillam's concept, as it concerns the IRB related practices.

Although Christians (2000), American professor of Communications, does not precisely define formal ethics, he summarizes four elements that are often stated and observed by an IRB, namely: (i) informed consent, (ii) deception, (iii) privacy and confidentiality, and (iv) accuracy. As to guarantee the first one (viz. informed consent), two instances ought to be considered. One relates to research participants voluntarily agreeing to participate and the other, to their agreement being based on " $[. .$. full and open information" (CHRISTIANS, 2000, p. 144). Regarding the second one, the author argues that a utilitarian perspective allows it (viz. 
deception) solely when the benefits from it achieves a larger number of individuals. However, "[...] deliberate misrepresentation is forbidden" (CHRISTIANS, 2000: 145).

The third one (viz. privacy and confidentiality) concerns the real possibility of safeguarding research participants' identities and personal information. Despite the fact that research proponents state that they will guarantee it, "[p]seudonyms and disguised locations often are recognized by insiders. What researchers consider innocent is perceived by participants as misleading or even betrayal" (CHRISTIANS, 2000, p. 145). The forth one (viz. accuracy) relates to the idea that "[f]abrications, fraudulent materials, omissions, and contrivances are both nonscientific and unethical" (CHRISTIANS, 2000, p. 145).

Reis and Egido (2017), Brazilian applied linguists, state that they endorse both Cameron et al's (1992) and Christians's (2000) terminologies, ethics and formal, respectively. Ethics research for Cameron et al (1992) and formal ethics for Christians (2000) stand for the same of bureaucratic ethics for Reis and Egido (2017). In sum, I conclude that the four terminologies (viz. procedural ethics, macroethics, formal ethics, and bureaucratic ethics) bear the same meaning.

\subsection{Illustrations}

The examples I display herein are the result of both online searches and research reports that I read previously to the production of this paper. Bearing in mind the geographical variety from where the terminologies were designed (viz. North American (CHRISTIANS, 2000), Australian (GUILLEMIN; GILLAM, 2004), Brazilian (REIS; EGIDO, 2017), and British (KUBANYIOVA, 2008)), I display two examples: one by De Costa $(2014 ; 2015)$ and one by Egido and Reis (2019).

In both publications (2014; 2015), De Costa, an applied linguist working in an American university, adopts the term macroethics to refer to his interactions to the research participants. In broaden terms, the author narrates the adoption of formal ethical research practices, namely: the submission of his investigation to an IRB and the assurance of safeguarding 
participants' anonymity, among others. His critical ethnographic study was conducted in an English-medium secondary school in Singapore ${ }^{5}$.

In their documental investigation, Egido and Reis (2019) synthesize ethical practices adopted by Brazilian applied linguists. Those practices refer to possibilities to safeguard participants' anonymity, to obtain their agreement, to portray them on the research report, so on so forth. Their study stresses a range of possibilities that applied linguists can observe and follow as they materialize the traditional ethics perspective.

\subsection{Synthesis}

As I reflect upon the IRB's responsibilities, which are to protect research participants, it is its endeavor to assess research proposals, but "the IRB do not elaborate upon the principles and values employed to asses a research proposal"6 (DUCET, 2000, p. 5). Therefore, the IRB does not possess full independence to legislate on unexpected conflicting research proposals. This hiatus is perceived by all areas of study.

In the Applied Linguistics precisely, the adoption of the research practices prescribed by the traditional ethics perspective, although important, had not embraced other ethical dilemmas ${ }^{7}$ with which they faced during the conduction of their investigations (e.g. DE COSTA, 2014; 2015). In order to respond to such ethical dilemmas and or other specific research elements, I then present the emergent ethics perspective.

In sum, I realized that all the terminologies displayed in this section to refer to the traditional ethics perspective are an example of monosemy, that is, all the terminologies bear the same meaning, although their authors adopt different terms. To put it differently, applied linguistics researchers have at their disposal a variety of lenses (viz. bureaucratic, formal, macroethics, and procedural) to read the same phenomenon (viz. traditional ethics in research).

${ }^{5}$ Even though he also discusses the microethical dimension, I save it to another moment.

${ }^{6}$ In French language: "Les comités n'établissent pas les principes et les valeurs à partir desquels ils vont juger la nature éthique d'un projet."

${ }^{7}$ They will be further conceptualized. 


\section{Emergent perspective on ethics}

The same scholars that proposed terminologies related to the traditional ethics perspective also made propositions to refer to the emergent one. The use of the attribute 'emergent' refers to the socially and situated emergent ${ }^{8}$ concepts. On the following paragraphs, I first underscore the terminologies (viz. emancipatory (REIS; EGIDO, 2017), social (CHRISTIANS, 2000), macroethics (KUBANYIOVA, 2008), and in practice (GUILLEMIN; GILLAM, 2004)), as well as heed to maintain and indicate their singularities. Then, I conceptualize and illustrate the term 'ethical dilemma', which is iterant on this perspective.

For Kubanyiova (2008, p. 504), macroethics " [...] refers to everyday ethical dilemmas that arise from the specific roles and responsibilities that researchers and research participants adopt in specific research contexts". From her understanding, I feature the references to 'ethical dilemmas' and 'contexts', which I envision will be recurrent on the other publications, too.

Guided by utilitarian philosophers and feminist scholars, Christians (2000, p. 149 - emphasis added) argues that "[...] social ethics rests on a complex view of moral judgments as integrating into an organic whole various perspectives - everyday experience, beliefs about the good, and feelings of approval and shame-in terms of human relations and social structures". When it comes to research participants' roles, the author states that they are supposed to participate during the whole process and they "[...] are given a forum to activate the polis mutually" (CHRISTIANS, 2000, p. 151). Nonetheless, the scholar lacks on examples of how these research participants' active roles could be materialized in social science investigations.

Instead of practical illustrations, the author mentions one type of research that may properly nourish the research participants' active roles, which is the feminist communitarian model. As I interpret the author's displayed characteristics, I argue that studies carried out within both the

${ }^{8}$ Hence, emergent depicts social and situated ethical practices that emerge from researchers' conduct of their investigations. The term does not mean these concepts came first than those from the 'traditional ethics perspectives', because the concepts are binomials. For instance, macroethics was conceptualized on the same publication that microethics was (KUBANYIOVA, 2008). 
constructivism and the participatory paradigms may also promote the research participants' active roles (LINCOLN; GUBA, 2000).

There has been just one emergent terminology proposed on the Brazilian literature to depict the ethics in Applied Linguistics research, which is by Reis and Egido (2017). In the authors' viewpoint,

The emancipatory ethics goes beyond the formal ethics because the research proponent necessarily returns, more than one, if it is necessary, the analyses to the participants before concluding the research report. The emancipatory ethics practices advocates this return aiming at strengthening the participants' position. It is achieved by means of power division related to the analysis, of incorporation of participants' voices in the research report, of possibility of learning with (and, why not, about) the research [...] . This ethics allows researchers and participants to register what they have learned during the research process. ${ }^{9}$ (REIS; EGIDO, 2017, p. 240 - emphasis added)

In their standpoint, emancipatory ethics is directly concerned with power relations and the learnings both researchers and participants can mutually construct by means of their relations during the study. Reis and Egido's (2017) remarks are in compliance with Christians' (2000) discussion of participants' active roles. The Brazilian scholars recommend that researchers return their analyses to their respective participants so then they can comment on, learn from, and suggest at such analyses.

Relying on Reis and Egido's (2017) viewpoint on ethics in research, Chimentão and Reis (2019, p. 707) comment that:

[...] it is not a question of returning the knowledge produced for information to the participant, but to scrutinize and discuss it, both

${ }^{9}$ In Portuguese language: “A Ética Emancipatória vai além da ética formal, pois quem realiza a pesquisa necessariamente retorna aos participantes com as análises, fazendo mais de uma vez, se necessário, antes de finalizar o relato da pesquisa. A Ética Emancipatória pratica o caminho de volta com a finalidade de fortalecer a posição do participante, pelo exercício de divisão de poderes sobre a análise, pela incorporação de sua voz no relato final, pela possibilidade de aprender com (e, por que não, sobre) a pesquisa [...]. Essa ética permite que pesquisadores e participantes registrem o que aprenderam também com essa fase da construção de conhecimento". 
to avoid negligence and/or failures with the participants and to review positions and statements, which ultimately make up the knowledge to be offered beyond the context in which it was constructed.

Guillemin and Gillam (2004, p. 263) conceptualize ethics in practice as "[...] the everyday ethical issues that arise in the doing of research". The authors support the necessity of this term, in contrast to the procedural ethics, as:

[t]hese issues are not usually addressed in research ethics committee applications, nor are they events that are often anticipated when applying for approval. Some researchers may not even regard them as ethical in the sense that they may not be "dilemmas" or appear to be of great consequence. (GUILLEMIN; GILLAM, 2004, p. 264)

Clark and Sharf (2006), Guillemin and Gillam (2004) ${ }^{10}$, and Kubanyiova (2008) ensure that ethical dilemmas emerge from the research process. Guillemin and Gillam (2004, p. 262) conceive 'ethical dilemmas', which stand out as a synonym for "ethical issues", as "[...] the "ethically important moments' in doing research - the difficult, often subtle, and usually unpredictable situations that arise in the practice of doing research". The authors go further as they state that these phenomena "[...] refer to situations in which there are a stark choice between different options, each of which seem to have equally compelling ethical advantages and disadvantages" (GUILLEMIN; GILLAM, 2004, p. 264-265). In general terms, ethical dilemmas are "[...] problem[s] of conscience" (CLARK; SHARF, 2006, p. 2).

${ }^{10}$ On the one hand, it is important to mention that, in Guillemin and Guillam's (2004), researchers in the Health Sciences, "ethically important moments" stands for "[...] the difficult, often subtle, and usually unpredictable situations that arise in the practice of doing research" (p. 262), whereas "ethical dilemmas" stands for "the life and death issues more typical in health care" (electronic personal message from July $\left.01^{\text {st }}, 2020\right)$. On the other hand, I inform that I follow both Clark and Sharf (2006) and Kubanyiova (2008), researchers in the Educational Sciences, and take such terms as synonyms. 
Taking into account the examples displayed and discussed by all these scholars, I understand that their definitions relate to the same phenomena. Drawing on such definition, I herein center on one example.

On their publication, Clark and Sharf (2006, p. 401) focus on four ethical dilemmas, which relate to "[....] the sometimes problematic perception of truth", they have faced in past investigations. To my purpose on this study, I recall one of them to illustrate what an ethical dilemma may be. It concerns "[...] a life history interview with an incarcerated woman who, because of the dynamics of a caring interview within the dehumanizing context of the prison, shared deeply personal information that had heretofore been secret" (CLARK; SHARF, 2006, p. 403).

Prior to conducting the interviews with this incarcerated woman and others, the researchers submitted and got approved their study design by an IRB. Regardless this and other formal ethics practices employed, the researchers faced an unexpected situation, an ethical dilemma. As they conducted the first interview with one inmate, she felt confident enough to tell her true story; something she had not told even to the other inmates. She was falsely accused of harming a child, which would certainly lead her to personal physical harm in the prison by the other inmates, that was why she kept the secret and did not tell them, but did to the researchers.

During the second meeting interview, the incarcerated woman did not mention the story again and the researchers did not question about it, either. The ethical dilemma rises as the researchers questioned themselves whether they could use this data. Even though the woman agreed to participate in the study, was she truly aware about the possibility of withdrawing from the investigation? The researchers decided not to analyze such data, which could put her safety into jeopardy.

In terms of formal ethics, Clark and Sharf (2006) did observe all the requirements, but they did not foreclose the ethical dilemma that emerged from the study agenda. This case supports Guillemin and Gillam's (2004) aforementioned excerpt that 'ethical dilemmas' are not necessarily foreseen by IRBs.

In synthesis, all the scholars' enterprise to propose a term that best characterizes their social and situated viewpoint of ethics in research is noteworthy. Each one of them attain it by emphasizing key issues that matter to their specific contexts. For instance, on the one hand, Reis and Egido (2017) highlight the researcher's return with the analyses to the participants, 
that is, a dialogic interaction. On the other hand, Clark and Sharf (2006) lay emphasis on ethical dilemmas that emerge from participants' sometimesunaware vulnerable position.

\section{Coexistence of the traditional and the emergent perspectives on ethics}

At the end of both previous sections, I argue that the terminologies addressed in both dimensions, that are, traditional and emergent, coexist. In none of the theoretical papers revised, the authors indicate others terminologies, except for Reis and Egido (2017) that refer to Cameron et al (1992) and Christians (2000). Therefore, they do not clearly justify why they propose a concept instead of adopting an existing one. By my review, I conclude that such conceptual propositions are supported by their local realities, theoretical repertoires and worldviews.

On chart 1 , I synthetize both dimensions regarding their focuses, terminologies, researcher-researched relations, and ethical elements covered. In terms of their focuses, I reason their traditional ethics perspective aim to observe institutional research norms, whereas emergent ethics perspective, to observe ethical dilemmas related to voice and power that emerge before, during, and after the research.

Relating to the terminologies adopted, they are the ones aforementioned on the two sections above. On the one hand, the traditional ethics perspective contemplates the following attributes: bureaucratic (REIS; EGIDO, 2017), formal (CHRISTIANS, 2000), macroethics (KUBANYIOVA, 2008), and procedural (GUILLEMIN; GILLAM, 2004). On the other hand, the emergent ethics perspective welcome the following attributes: emancipatory (REIS; EGIDO, 2017), social (CHRISTIANS, 2000), macroethics (KUBANYIOVA, 2008) and in practice (GUILLEMIN; GILLAM, 2004).

The researcher-researched relations are fluid, and recurrent features led me to this interpretation. In the traditional ethics perspective, the relation is frequently distant between the researcher and the participants, taking into account that the ethical care lies on the IRB procedures, mostly. Nonetheless, there are circumstances in which the researcher is required to negotiate participants' benefits with them (e.g. DE COSTA, 2014; 2015). 
Even though the participants' benefits matter is foreseen by research norms, followed by IRBs, the way such benefits are stablished to specific kinds of participants is situated contextually. Sometimes, it is necessary that the research proponent talks to the participants and negotiate it with them previously and during the study. In sum, in this perspective, researcherresearched relation is generally distant, but in exceptional cases, it is close.

In the emergent ethics dimension, researcher-researched relations are generally close. This dialogic interaction is driven by scholars', participants', and context's either demands or necessities. This kind of interaction is embedded by contextual, cultural, and historical traits. This close relation is necessary as the participants' agenda is equally taken into account.

The traditional ethics dimension cluster a few ethical elements, which are prescribed in Brazilian federal research regulations (e.g. CONSELHO NACIONAL DE SAÚDE, 1988; 2016) and in British association (e.g. BRITISH EDUCATIONAL RESEARCH ASSOCIATION, 2011; 2018), for instance. The elements are: anonymity; informed consent; submission to an IRB.

In the emergent ethics dimension, room is created to ethically reflect upon the data, the analysis, the research report sharing, and the researcher's langue use $^{11}$. Such reflections are often led by dialogism and ethical dilemmas. When interpreted that these phases are not researcher-end only, spaces are proposed to participants' active role, that is, to hear their voices regarding the data, the analysis, and the research report. By doing so, researchers may also problematize the idea of obtaining one single participants' consent; as I argue that it should be continuous.

\footnotetext{
${ }^{11}$ Although not extensively discussed, this last element is crucial as I reflect upon researcher's power when writing about the participants. I understand that all researchers bear the power of either oppressing or empowering the participants by means of their representation in the research report.
} 
Chart 1. Synthesis of the traditional and the emergent perspectives

\begin{tabular}{|l|l|l|}
\hline & \multicolumn{1}{|c|}{$\begin{array}{c}\text { Traditional ethics } \\
\text { perspective }\end{array}$} & \multicolumn{1}{|c|}{$\begin{array}{c}\text { Emergent ethics } \\
\text { perspective }\end{array}$} \\
\hline Focus & $\begin{array}{l}\text { To observe institutional } \\
\text { research norms }\end{array}$ & $\begin{array}{l}\text { To observe ethical dilemmas } \\
\text { related to voice and power } \\
\text { that emerge before, during, } \\
\text { and after the research }\end{array}$ \\
\hline Terminology & $\begin{array}{l}\text { Bureaucratic (REIS; } \\
\text { EGIDO, 2017) } \\
\text { Formal (CHRISTIANS, } \\
\text { 2000) } \\
\text { Macroethics } \\
\text { (KUBANYIOVA, 2008) }\end{array}$ & $\begin{array}{l}\text { Emancipatory (REIS; } \\
\text { EGIDO, 2017) } \\
\text { Social (CHRISTIANS, 2000) } \\
\text { Macroethics } \\
\text { (KUBANYIOVA, 2008) } \\
\text { In practice (GUILLEMIN; } \\
\text { GILLAM, 2004) }\end{array}$ \\
\hline $\begin{array}{l}\text { Procedural (GUILLEMIN; } \\
\text { GILLAM, 2004) }\end{array}$ & $\begin{array}{l}\text { Researcher- } \\
\text { relation }\end{array}$ & Close, sometimes \\
\hline $\begin{array}{l}\text { Ethical } \\
\text { elements } \\
\text { covered }\end{array}$ & $\begin{array}{l}\text { Anonymity; informed } \\
\text { consent; submission to an } \\
\text { IRB }\end{array}$ & $\begin{array}{l}\text { Close, generally; } \\
\text { Distant, hardly ever } \\
\text { report sharing; dialogism; } \\
\text { ethical dilemmas; } \\
\text { researcher's language use }\end{array}$ \\
\hline
\end{tabular}

Source: the author

As I peruse the constituting elements of both dimensions, I deem that they coexist, instead of being excluding. In other words, the adoption of traditional ethics perspective does not prevent the emergence of ethical dilemmas. The close care from the researcher to the participants also does not replace the necessity of submitting the research proposal to an IRB.

Although I advocate for the adoption of both dimensions in any applied linguistics research, it is necessary to reiterate "[...] certain macroethical principles are inadequate to offer guidelines for situated research practices and can in fact be at odds with microethical considerations" (KUBANYIOVA, 2008, p. 504 - emphasis added). In accordance to Kubanyiova's remarks, Christians also comments on the gaps identified on the ethics dimensions.

Although Christians (2000) does not precisely state a definition to formal ethics, he mobilizes consequentialist philosophers to problematize the practices carried out by IRB. According to him, it is implicit on this 
institution the premise that "[p]rofessors should hang up their values along with their coats as they enter their lecture halls" (CHRISTIANS, 2000, p. 142). In other words, as researchers submit their studies design to an IRB, they should eliminate all biases and values. Christians (2000) goes on questioning this premise. In his viewpoint, "[w]hat appears neutral on paper is often conflictual in practice" (CHRISTIANS, 2000, p. 145).

In synthesis, two dimensions/perspectives have been built to relate to researchers' deeds concerning their participants. In current times, I see it as impossible to pretend not to see the ethical institutional norms and dilemmas that emerge and expand around researchers and applied linguists, specifically.

\section{Closing remarks}

My purpose, initially stated on the introduction, was to argue that the adoption and discussion of ethics in research is not solely related to physical or intentional harm. To achieve this goal, I reviewed North American (CHRISTIANS, 2000), Australian (GUILLEMIN; GILLAM, 2004), Brazilian (REIS \& EGIDO, 2017), and British (KUBANYIOVA, 2008) theoretical papers that conceptualize ethics dimensions in research.

My findings indicated the existence of a variety of concepts of ethics in research and, consequently, some practices, which were either prescribed by institutions by means of their institutional documents (viz. EGIDO, 2019) or emerged from scholars' research agendas (viz. CHIMENTÃO; REIS, 2019).

From these findings, I consider it is noteworthy to suggest that applied linguists, when adopting a concept of ethics, do so with clarity and aware of its specific traits. Additionally, they should mention and discuss this topic, that is, ethics in research, in their research reports, so their readers may understand their care for the other. This recommendation may be extended to the area, as it shall consider such diversity of terms. When applied linguists consider the research ethical dimension, it is imperative that they materialize it on their research reports.

As applied linguists become aware of concepts, clustered in the traditional and emergent ethics dimensions, they might refute the (false) assumption that an investigation could be carried out without ethical 
considerations. I state this recommendation because "[...] the ethical dimensions of SLA [Second Language Acquisition] research appeared to be eschewed or at least left implicit in many publications" (ORTEGA, 2005, p. $317)$.

Throughout this paper, I have advocated for the opposite of that (false) assumption: all investigations are vested with ethical worldviews from their proponents, even though some of them do not discursively materialize them on their research reports.

Finally, I would like to reflect briefly on the ethics, traditional and emergent, I employed on this article. By following Brazilian institutional research norms (CONSELHO NACIONAL DE SAÚDE, 2016), I was not required to submit the proposal of this paper to an IRB, due to its theoretical nature. From the beginning, I realized I would not be able to safeguard the identities of the scholars, who authored the papers I reviewed here. As so, I felt it was an imperative to share my reflections with those scholars. By doing so, it was possible to establish a genuine dialogic interaction through which we could both learn from.

Another ethical element I implicitly included on this theoretical paper refers to my caution of not judging one scholar proposition as better than the others. As I aforementioned, all concepts reviewed are equally relevant and both socially and theoretically situated. This reflection to my own language use throughout this paper is anchored in the emergent ethics dimension.

\section{References}

ANDRADE, O. G. Ética em pesquisas envolvendo seres humanos. Londrina: EDUEL, 2017.

BRITISH EDUCATIONAL RESEARCH ASSOCIATION. Ethical guidelines for educational research. 4th ed. 20 jun 2018. Available at: <https://www.bera.ac.uk/researchersresources/publications/Ethical guidelines-foreducational-research-2018>. Accessed on 06 jan 2020.

BRITISH EDUCATIONAL RESEARCH ASSOCIATION. Ethical guidelines for educational research. 2011. Available 
at: $<$ https://www.bera.ac.uk/wp-content/uploads/2014/02/BERA-EthicalGuidelines-2011.pdf?noredirect=1>. Accessed on 02 mar 2018.

CAMERON, D. et al. Researching language: issues of power and method. New York, NY: Routledge, 1992.

CHIMENTÃO, L. K.; REIS, S. Beyond bureaucratic ethics in qualitative research involving human beings. Alfa, v. 63, n. 3, p. 697-715, 2019.

CHRISTIANS, C. G. Ethics and Politics in Qualitative Research. In: DENZIN, N. K.; LINCOLN, Y. S. (Ed). Handbook of qualitative research. Thousand Oaks, SAGE, 2000, p. 253-291.

CLARK, M. C.; SHARF, B. F. The dark side of truth(s): ethical dilemmas in researching the personal. Qualitative inquiry, n. 13, v.3, p.399-416. 2006.

CONSELHO NACIONAL DE SAÚDE. Resolução CONEP nº 001/1988, de 14 de janeiro de 1987. Dispõe sobre normas em pesquisa envolvendo seres humanos. Diário Oficial da República Federativa do Brasil, Brasília, 14 jan 1988.

CONSELHO NACIONAL DE SAÚDE. Resolução CONEP n ${ }^{\circ}$ 510/2016, de 07 de abril de 2016. Dispõe sobre normas em pesquisa envolvendo seres humanos. Diário Oficial da República Federativa do Brasil, Brasília, 07 apr 2016.

DE COSTA, P. I. Making ethical decisions in an ethnographic study. TESOL Quarterly, Virginia, n.2, v.48, p.413-422. 2014.

DE COSTA, P. I. Ethics and Applied Linguistics Research. In: PALTRIDGE, B.; PHAKITI, A. (Ed.). Research methods in applied linguistics. New York: Bloomsburry, 2015, p.245-257.

DE COSTA, P. I. (Ed.). Ethics in Applied Linguistics research: language researcher narratives. New York, NY: Routledge, 2016. 
DOUCET, H. Les silences éthiques de l'éthique de la recherche. Revue Internationale D'Éthique Sociétale et Gouvernamentale, [s.1.], v. 2, n. 2, 2000, p. 1-8.

DWYER, A. Ética y aspectos prácticos del trabajo de campo cooperative. In: HAVILAND, J.; FARFAN, A. F. (Ed.). Bases de la documentación linguística. Mexico City: Instituto Nacional de Lenguas Indígenas, 2007, p. 49-89.

EGIDO, A. A. O eu e o outro: uma breve história da ética em pesquisa em linguística aplicada. 2019. 353 f. Dissertação (Mestrado em Estudos da Linguagem) - Universidade Estadual de Londrina, Londrina, 2019.

EGIDO, A. A.; REIS, S. Procedimentos éticos em pesquisa em estudos da linguagem. In: ALMEIDA FILHO, J. C. P.; OLIVEIRA, L. E.; FONSECA, A. L. S. B. (Org.). História, políticas, ética e epistemologia de área na formação docente. Campinas: Pontes, 2019, p. 103-123.

FOUCAULT, M. Madness and civilization. New York, NY: Pantheon, 1988 [1961]. Translated from Historie de la Folie.

GUILLEMIN, M.; GILLAM, L. Ethics, reflexivity, and "ethically important moments" in research. Qualitative inquiry, California, n.10, v.2, p.261 280. 2004.

HAGGERTY, K. D. Ethics creep: governing social science research in the name of ethics. Qualitative sociology, Netherlands, v.27, n.4, p.391-414. 2004.

HAMID, M. O. Fieldwork for language education research in rural Bangladesh: ethical issues and dilemmas. International Journal of Research \& Method in Education, California, v. 33, n. 3, p. 259-271, 2010.

HELSINKI DECLARATION. Recommendations guiding doctors in clinical research. 2018. 
KUBANYIOVA, M. Rethinking Research Ethics in Contemporary Applied Linguistics: The Tension Between Macroethical and Microethical Perspectives in Situated Research. The Modern Language Journal, London, n.92, v.4, 2008, p.503-518.

LÉVY, J. J.; BERGERON, M. Éthique de la recherche et responsabilité sociale du chercheur: perspectives canadiennes et québécoises. Revue Internationale D'Éthique Sociétale et Gouvernamentale, [s.1.], v. 12, n. 1, 2010, p. 1-7.

LINCOLN, Y. S.; GUBA, E. G. Paradigmatic Controversies, Contradictions, and Emerging Confluences. In: DENZIN, N. K.; LINCOLN, Y. S. (Ed). Handbook of qualitative research. Thousand Oaks, SAGE, 2000, p. 253-291.

NUREMBERG CODE. 1949. Available at: <https://history.nih.gov/research/downloads/nuremberg.pdf $>$. Accessed on 28 apr 2020.

ORTEGA, L. For What and for Whom Is Our Research? The Ethical as Transformative Lens in Instructed SLA. The Modern Language Journal, v.89, n.3, p.427-443, 2005.

REIS, S.; EGIDO, A. A. Ontologia, Epistemologia e Ética como determinantes metodológicos em Estudos da Linguagem. In: REIS, S. (Org.). História, políticas e ética na área profissional da linguagem. Londrina: Eduel, 2017. p. 227-250.

UNITED NATIONS. Universal declaration of human rights. 1948.

Submetido em: 20/07/2020

Aceito em: 09/12/2020

Título: Conceitos de ética na pesquisa em Linguística Aplicada 